\title{
Reproductive biology of the endangered percid Zingel asper in captivity: a histological description of the male reproductive cycle
}

\author{
Christine Chevalier, Christine de Conto, Jean-Marie Exbrayat
}

\author{
University of Lyon, General Biology Laboratory, UCLy, Laboratory of Reproduction \\ and Comparative Development, EPHE, Lyon, France
}

\begin{abstract}
The endemic Rhodanian percid Zingel asper (Linnaeus, 1758), is usually found throughout the Rhône basin, but this fish is now in sharp decline. Understanding its reproductive physiology is important so as to be able to artificially control its reproduction with a view to re-introducing it. This study was carried out on a population obtained by artificial fertilization and bred in external tanks. Fishes were observed from the juvenile stages through to adulthood. Patterns of testicular development were defined from histological observations. Testes of $Z$. asper were paired, elongated and fusiform dorsocaudal organs. The two lobes of each gonad joined together to form a duct that extended to the urogenital papillae. They showed a lobular structure. The testicular lobules were of the unrestricted spermatogonial type. Up to 10 months-old, most of the males were immature: their testes showed only type A spermatogonia. The appearance of type B spermatogonia in the lobules of a testis indicated the beginning of spermatogenesis in 10 months-old fish. Spermiogenesis occurred 24 months after the fertilization and, in 26 months-old fish, the cyst opened and released spermatozoa into the lumen of lobules. The spermiation belonged to a cystic type. During the third year, histological observations pointed to the same evolution of adult gonads as during the second year. Sexual maturity was reached in captive $Z$. asper after two years. The spawning occurred in May in the breeding conditions. (Folia Histochemica et Cytobiologica 2011, Vol. 49, No. 3, 486-496)
\end{abstract}

Key words: Zingel asper, testis development, sexual maturity, reproductive cycle, histology

\section{Introduction}

Testis structure and spermatogenesis in teleost species have been extensively studied in adult fish, generally from natural populations [1,2], and most especially in perciform species [3-7]. During spermatogenesis, when germ cells differentiate from spermatogonia to spermatozoa $[8,9]$, the germ cells go through three major phases: mitotic proliferation (spermatogonial stem cells to differentiated spermatogonia [SPG]), meiosis (spermatocytes [SPC] to spermatids [SPD]), and spermiogenesis (SPD to spermatozoa [SPZ] $[10,11]$.

Correspondence address: Ch. Chevalier, University of Lyon, General Biology Laboratory, UCLy, Laboratory of Reproduction and Comparative Development, EPHE, 25 rue du Plat, F-689288 Lyon Cedex 02, France; e-mail: cchevalier@univ-catholyon.fr
Within the germinal compartment, separated from the interstitial compartment by a basement membrane [4, 12], Sertoli cells envelop spermatocysts containing isogenic germ cells at the same stage of development $[13,14]$. Among teleost species, Mattei et al. [15] have distinguished cystic from semi-cystic types of spermatogenesis. In the cystic type, spermatogenesis is completed within spermatocysts that break down at the end of spermiogenesis, releasing only spermatozoa into the lumen of lobule. In the semicystic type, spermatogenesis occurs partly outside the cysts. In perciform species, germinal compartments that extend to the periphery of the testis and terminate blindly are termed lobules, not tubules [16-19]. Both types of testis can be further divided into an unrestricted spermatogonial testis-type, in which spermatogonia can be found all along the lobules, and a restricted spermatogonial testis-type, in which spermatogonia are restricted to the distal part of them 
$[3,4,16,17,20]$. The interstitial compartment is made up of connective tissue in which myoid cells, Leydig cells, blood vessels, fibroblasts and collagen fibers can be observed [4, 21-23].

The maturation of testes has been classified into anything from three [24] to nine stages [25, 26]. But the commonest definition sets out five stages: immature stage with resting testis; initialization of spermatogenesis or proliferation of spermatogonia; spermatogenesis during which all types of cells appear; spermiation; and a post spawning stage [4, 18, 27-31].

Reproduction is generally a seasonal activity, and the reproductive cycle depends on environmental parameters, particularly water temperature and photoperiod [32]. Knowledge of the seasonal cycle of gonad development is essential to understanding the reproductive physiology and ecology of a fish population $[33,34]$.

The Rhône streber, Zingel asper, (Linnaeus, 1758) is an endangered endemic percid fish found in the Rhône basin in France. It features on the 'red list' of the International Union for the Conservation of Nature.

The species is in sharp decline. Its distribution is now limited to less than $20 \%$ of the territory it previously occupied [35,36]. Little is known about the species, beyond its distribution [35, 37], diet and growth [38], demography [39, 40], habitat use [41, 42] and genetic structure of the largest populations [43]. The decline of $Z$. asper populations has been attributed to habitat fragmentation [44], hydraulic disturbance and pollution [45].

The reproductive physiology of immature and mature $Z$. asper has been investigated. The ovarian development has been described in detail for Rhône streber females [46]. In this present work, we describe for the first time the histological characteristics of spermatogenic cells and the stages of sexual maturation of testes in $Z$. asper.

This study also sought to establish the age of sexual maturity and to identify the reproductive period. A parallel with the cycle of females will be discussed. Furthermore, the present work is intended to support the control of artificial reproduction, so as to reintroduce the Rhône streber back into its natural environment.

\section{Material and methods}

Sampling. Male specimens of $Z$. asper (Rhône streber) were obtained by artificial fertilization in March 2000. The parents were from the Beaume River (a tributary of the Ardèche River). The cohort was bred in external tanks (Allex, Drôme, France) continuously supplied with ground water from the Drôme River. Fish were bred in outdoor tanks, so they were exposed to a natural photoperiod. The tanks were supplied with spring water, the temperature of which varied from $9^{\circ} \mathrm{C}$ to $14^{\circ} \mathrm{C}$ according to the time of year.

A total of 32 specimens were investigated, taken at different times from their first, second or third years of life. Male Z. asper were caught in October $2000(\mathrm{n}=3)$, January $2001(\mathrm{n}=3)$, March $2001(\mathrm{n}=2)$, May $2001(\mathrm{n}=2)$, July $2001(\mathrm{n}=1)$, September $2001(\mathrm{n}=3)$, January 2002 $(\mathrm{n}=2)$, March $2002(\mathrm{n}=4)$, May $2002(\mathrm{n}=4)$, July 2002 $(\mathrm{n}=1)$, March $2003(\mathrm{n}=5)$, April $2003(\mathrm{n}=1)$, and June $2003(\mathrm{n}=1)$. The fish were immediately anesthetized in a solution of phenoxy ethanol $(0.5 \%)$ and killed by spinal section. Parts of the testes were used for histological studies.

Histology. For histological analysis, the testes were removed, fixed in Bouin's solution for 24 hours at room temperature, dehydrated in an ethanol series and cleared in butanol prior to paraffin infiltration and embedding. The tissues were sectioned at $7 \mu \mathrm{m}$ and stained with modified azan (nuclear fast red for 15 minutes, molybdic orange $\mathrm{G}$ solution for five minutes, and aniline blue).

Sections of testes tissue were photographed using a Nikon Eclipse E400 microscope equipped with a Nikon digital DXM1200 camera coupled with a picture analyzer (Lucia software). The nuclei diameters of germinal cells were measured.

For scanning electron microscopy, pieces of testes were fixed in $1 \%$ glutaraldehyde, $0.5 \%$ paraformaldehyde in 0.1 $\mathrm{M}$ phosphate buffer ( $\mathrm{pH}$ 7.4). The fragments were taken through alcohol to acetone, then critical-point dried before being coated with a layer of gold and viewed with SEM (Hitachi S800) at $10 \mathrm{kV}$ at the Centre technologique des microstructures $(\mathrm{CT} \mu)$, Université Claude Bernard Lyon 1, Domaine Scientifique de la Doua - 5, rue Raphaël Dubois - 69622 Villeurbanne Cedex, France.

Statistics. The results (nuclei diameter) were expressed as average with standard error (average \pm SEM), with the number of samples (n). Differences between two results series were tested by means of Student's $t$ test. Significance was accepted for all tests at $\mathrm{p}<0.001$.

\section{Results}

\section{Organization of the testes}

A pair of elongated testes is situated in the dorsocaudal region of the body (Figure 1A). No seminal vesicle is observed. Each gonad contains a deferent duct running lengthwise, connected to the lumen situated in the center of each lobule (Figure 1B). The ducts merge just before the urogenital papilla.

The lobules are radially arranged around the deferent duct (Figure 2A). Type A spermatogonia are scattered throughout the testes. 

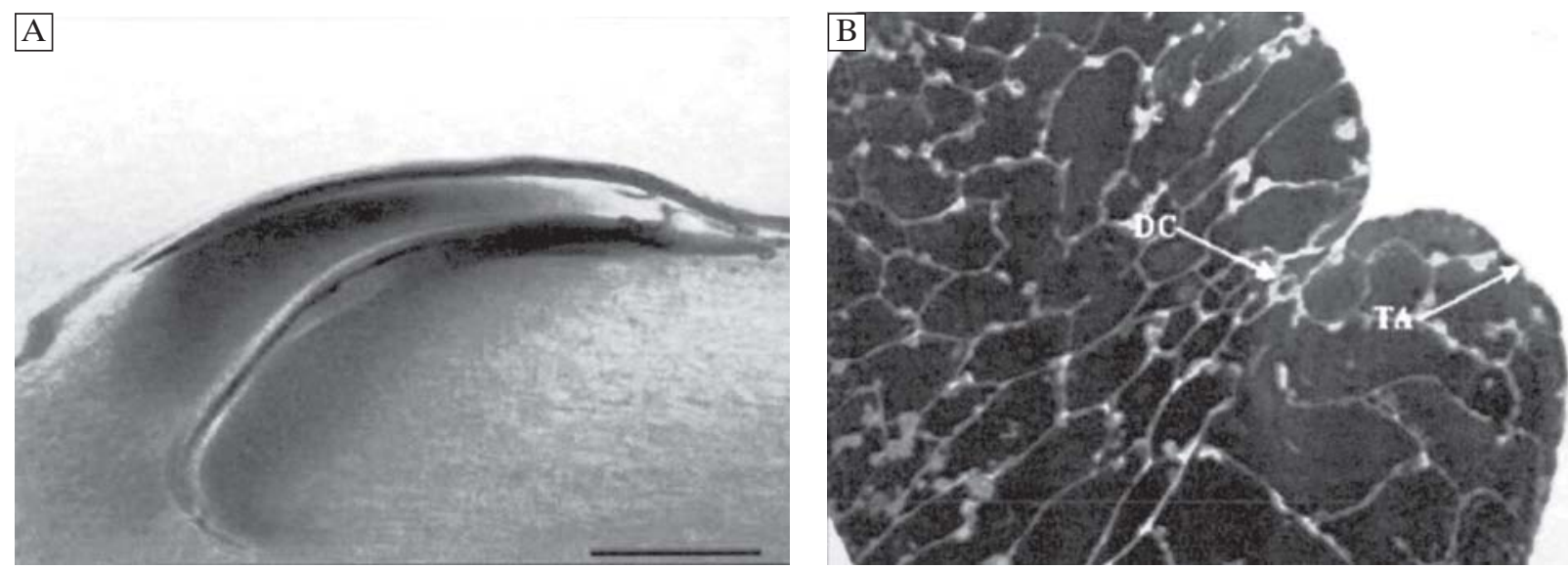

Figure 1. Zingel asper testis and testicular lobe, transversal section. Modified azan stained. A. Testis (a paired elongated organ) during resting sexual stage. Scale bar $=1 \mathrm{~cm}$. B. Transversal section of testicular lobe during spermiation showing deferent canal and testicular membrane: the tunica albuginea. Scale bar $=1 \mathrm{~mm}$. DC - deferent canal;

TA - tunica albuginea
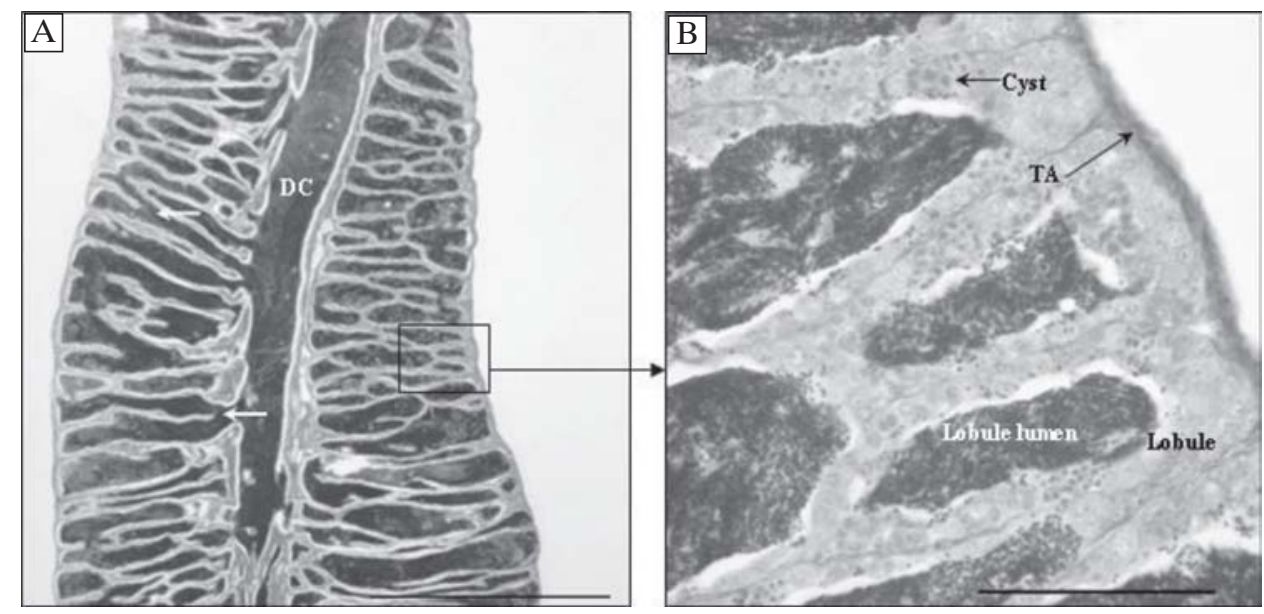

Figure 2. Zingel asper histological section of testis during spermiation. Modified azan stained. A. Longitudinal section of testis showing branching structure (arrow). Bar $=1000 \mu \mathrm{m}$. B. Detail of lobular structure showing centripetal migration of the cysts into a lobule. Scale bar $=100 \mu \mathrm{m}$. DC - deferent canal; TA - tunica albuginea

The germinal epithelium has a tripartite structure: an acellular basement membrane, Sertoli cells, and germ cells (Figure 3). In $Z$. asper, spermatogenesis occurs in cysts. Sertoli cells surround individual primary spermatogonia, and their cytoplasmic extensions enclose the border of spermatocysts containing the secondary spermatogonia. The division of spermatogonia is synchronous in a single spermatocyst, but all the cysts do not develop simultaneously (Figure 2B). The migration of cysts is centripetal, and consequently the cysts of both A and B spermatogonia are situated on the periphery of lobules, while the cysts of spermatocytes and spermatids are found in the center of lobules, close to the lumen (Figure 2B). During sexual maturation, cysts increase in size and, at the same time, in each cyst, cells increase in num- ber but decrease in size. On the outside of the basement membrane, the interstitial tissue contains connective fibers (Figure 3), blood vessels, Leydig cells, and myoid cells.

\section{Histological characteristics of spermatogenic cells of $\mathrm{Z}$. asper}

All the germ cell types were observed in $Z$. asper, on histological sections (Figure 4). Type A spermatogonia (SPGA) were individually surrounded by cytoplasmic processes of Sertoli cells clearly more basophilic than primary spermatogonia. SPGA were observed over the entire length of the lobule, whatever the stage. They were observed alone or in pairs near their edge. Generally, the peripheral lobules 


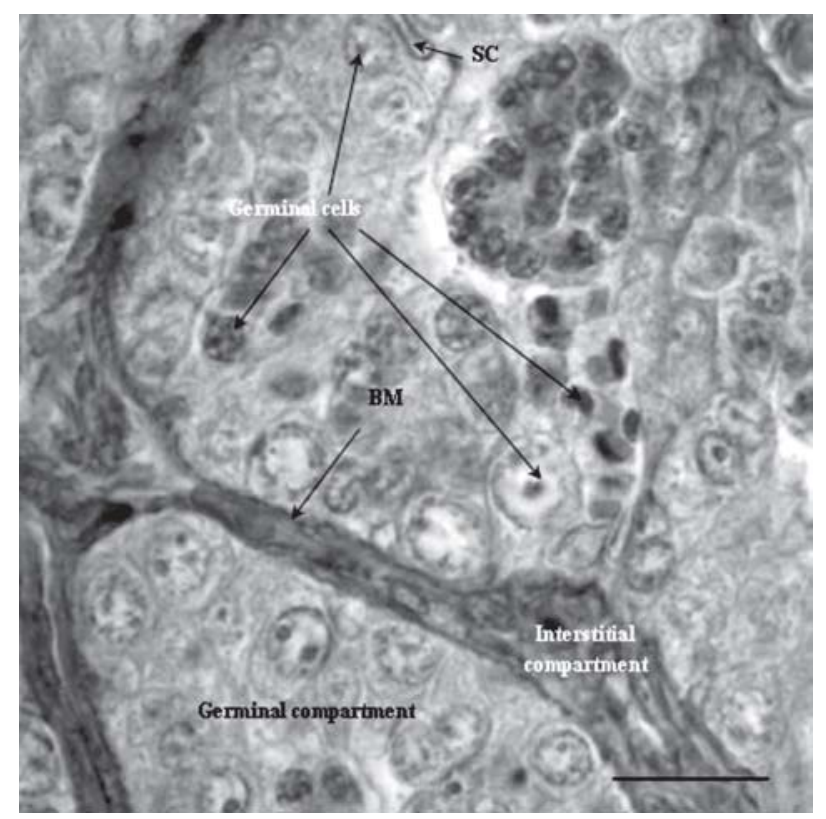

Figure 3. Zingel asper germinal epithelium during spermatogenesis. Modified azan stained. Scale bar $=100 \mu \mathrm{m}$. $\mathrm{BM}$ - basement membrane; SC — Sertoli cell

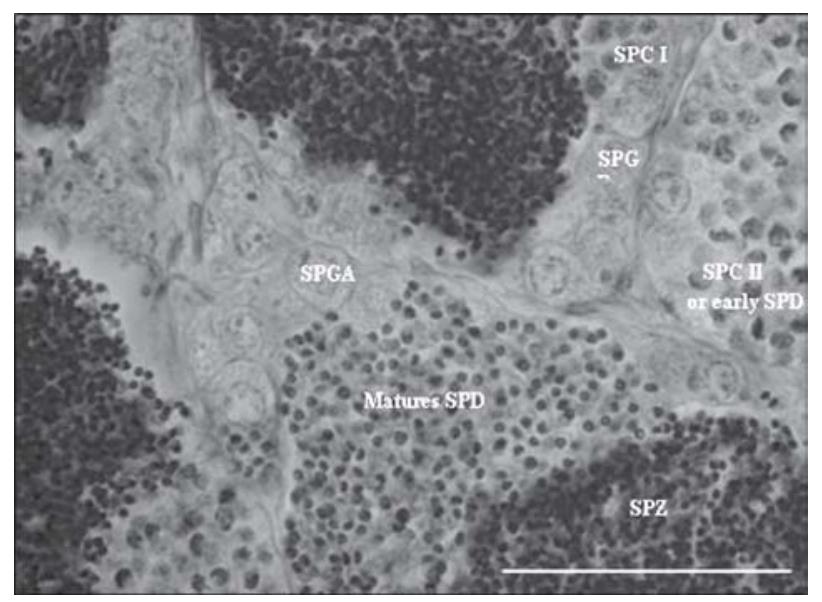

Figure 4. Different types of germinal cells in Zingel asper testis. Modified azan stained. Scale bar $=50 \mu \mathrm{m}$. SPGA — spermatogonia A; SPGB — spermatogonia B; SPC I — spermatocytes I; SPC II — spermatocytes II; SPD — spermatids; SPZ — spermatozoa

contained more spermatogonia than the more central ones. SPGA was the largest cell of the germ line and showed an ovoid or ellipsoid shape. The cellular membrane was tiny and difficult to see. SPGA possessed a prominent, large, pale, slightly oval or spherical nucleus, with a visible membrane. The nuclear diameter was $8,585 \pm 108 \mathrm{~nm}$ (min-max: $6,617-11,731 ; \mathrm{n}=100)$. The nucleus contained scattered chromatin and one or two basophilic large nucleoli. The SPGA cytoplasm was not very abun- dant. The nucleocytoplasmic ratio was low $(0.595 \pm$ $\pm 0.009 ; \mathrm{n}=38$ ).

The type B spermatogonia (SPGB), resulting from the mitotic division of primary spermatogonia, was confined within spermatocysts in clusters of two or more cells. These cells were significantly $(p<0.001)$ smaller than the type A ones. The nuclear diameter was $6,051 \pm 77 \mathrm{~nm}$ (min-max: 4,308-8,578; $\mathrm{n}=100)$. SPGB showed a little abundant cytoplasm with a nucleocytoplasmic ratio reaching $0.64 \pm 0.01 ; \mathrm{n}=38$. Considering the cytological characteristics, these cells looked like spermatogonia A.

After the last mitotic division, they gave rise to primary spermatocytes (SPC I), that were rounded and smaller than the spermatogonia, and grouped in cysts. The cell envelope of SPC I was not visible, and the cytoplasm was reduced. The nucleus was roundshaped and very basophilic. The nuclear diameter was $4,256 \pm 47 \mathrm{~nm}(\min -\max : 3,301-5,785 ; \mathrm{n}=139)$, and the chromatin was more granulated than the secondary spermatogonia one. Nucleoli became progressively more indistinct and disappeared.

Secondary spermatocytes (SPC II) result from the first division of meiosis. Observation of spermatocyte II was difficult owing to the speed of the second meiotic division, giving rise to the early spermatids. At this stage, the cytoplasm of germ cells was no longer visible using optical microscopy.

The nucleus was elongated in shape, refringent and very basophilic. As the chromatin condensed, a great reduction of the nucleus volume became obvious. The SPC II or early spermatid diameter was 3,354 $\pm 35 \mathrm{~nm}$ (min-max: 2,437-3,511; $\mathrm{n}=$ $=129$ ). As spermatids evolved, the chromatin migrated to one side. As spermiogenesis progressed, chromatin condensed, transforming from granular in early spermatid to homogeneous in mature spermatid. The late spermatids were still contained within the cysts. These cells were smaller than the early spermatids, with a diameter of $1,886 \pm 25 \mathrm{~nm}$ (min-max: 1,246-1,730; $\mathrm{n}=121$ ). The flagellum was observed. Late spermatids were transformed in spermatozoa during spermiogenesis.

Spermatozoa (SPZ) were the smallest germ cells, appearing as small spheres due to the high chromatin condensation (Figure 6B). The use of scanning electron microscopy (Figure 5) showed uniflagellate SPZ, with round heads and a very short middle piece. The heads of these cells were pointed towards the periphery of the cysts, jointed to the Sertoli cells. The tails were directed towards the lobule lumen. Hence, on histological sections, SPZ were sometimes observed in packages resembling 'parachutes'. Only SPZ were present in the lumen of lobule. 


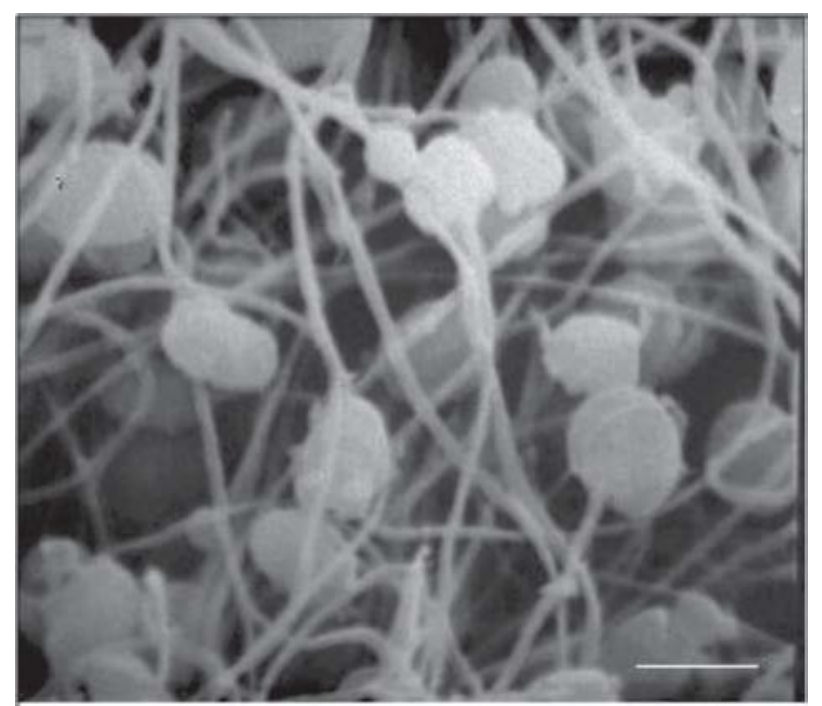

Figure 5. Sperm cell structure of Zingel asper observed with scanning electron microscopy. Scale bar $=1 \mu \mathrm{m}$

\section{Somatic cells}

Sertoli cells showed the typical elongated triangular nucleus and cytoplasm extensions, evident at the beginning of spermatocyst formation (Figure 6B). In the presence of SPC I, SPC II and SPD, Sertoli cells were no longer observed as a thin envelope which delimit the cysts. Figure $6 \mathrm{C}$ highlights the presence of cells in the lumen of lobule during resorption of unissued spermatozoa. These cells look like Sertoli cells associated with spermatogonia.

Leydig cells were situated in the interstitial compartment of the testis. They were observed on very few sections (Figure 7). They were located on the edges of blood vessels. Their cytoplasm was not very visible, the nucleus was elliptic with a scattered and not very basophilic chromatin; a nucleolus was observed in some of them.

Some few elongated cells, probably myoid cells, were observed, scattered in the interstitial tissue, close to the basement membrane of lobules.

\section{Stages of testes maturation and spermatogenesis in $\mathbf{Z}$. asper}

The testicles of $Z$. asper aged 7 to 39 months can be divided into three categories: those of immature fish, juvenile fish and adult fish.

The definitions of stages (testis maturation, spermatogenesis and spermiogenesis) were based on the relative amount of the various germ cell types. The histological observations showed that the annual cycle of adult fish testes pass through four stages of development: initial spermatogenesis, active spermatogenesis, spermiation and post spawning (Figure 8).
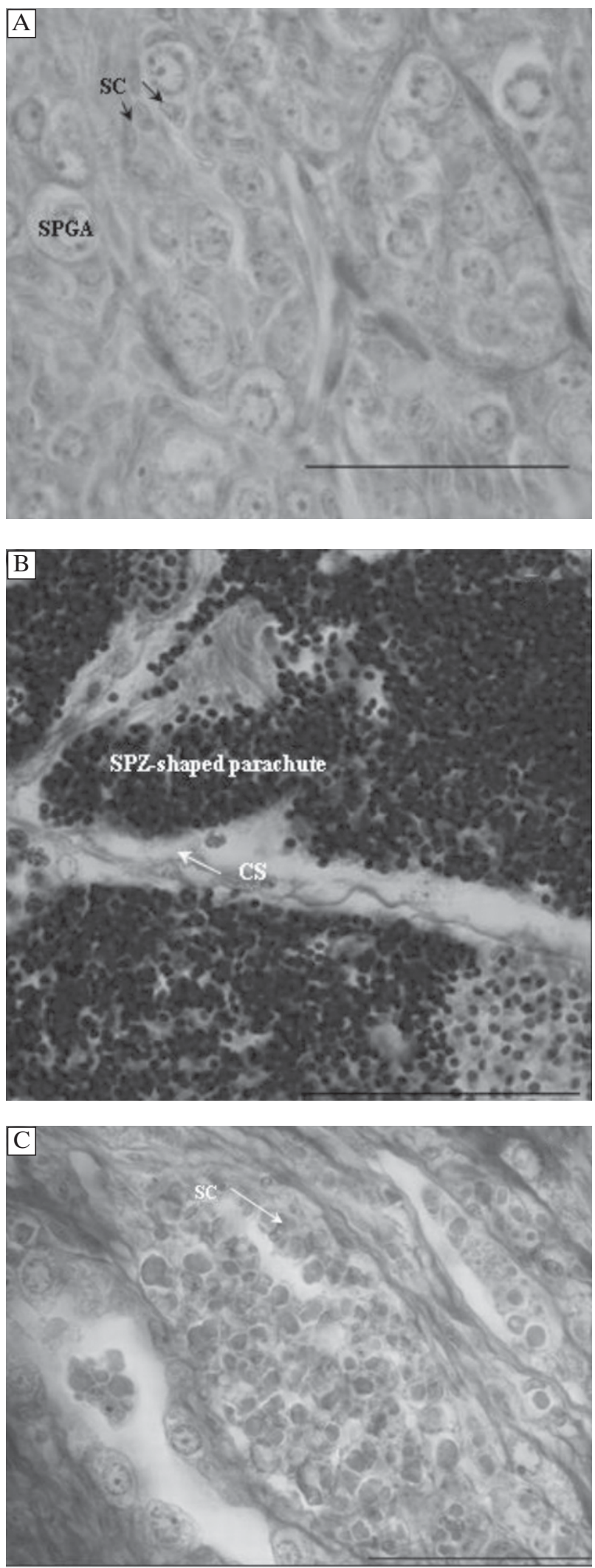

Figure 6. Histological sections of Zingel asper testis showing Sertoli cells. Modified azan stained. A. Into the lobules. B. In contact with spermatozoa showing a headshaped parachute. C. In the lobule lumen during resorption. Scale bar $=50 \mu \mathrm{m}$. SC - Sertoli cell; SPGA - spermatogonia A; SPZ — spermatozoa 


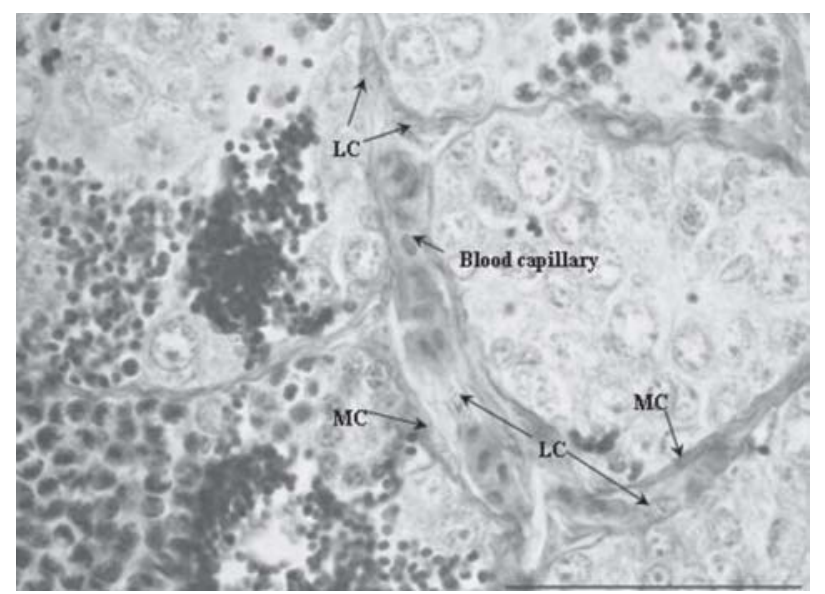

Figure 7. Histological sections of Zingel asper testis showing Leydig cells close to blood capillaries and myoid cells in the interstitial compartment. Modified azan stained. Scale bar $=50 \mu \mathrm{m}$. LC - Leydig cell; $\mathrm{MC}$ - myoid cell

The fish collected in 2000, seven months after fertilization, were immature. The testes were comparable to two thin ribbons (Figure 1A). Only type A spermatogonia were present on the sections (Figure 8A). The earliest signal of the onset of maturation was the presence of cystic structure containing type B spermatogonia. Three different situations occurred among the eight juvenile fish aged ten to 16 months. Four of them were in the initial spermatogenesis stage, showing only SPGA and SPGB in the cyst. One 12 month-old individual began active spermatogenesis. All the germ cell types, spermatogonia, spermatocytes, spermatids and spermatozoa, were present. The testes of this individual were swollen, which is a macroscopic characteristic of maturity. The three other individuals showed the presence of peripheral spermatogonia and reduced spermatozoa in the lumen of lobules.

The testes of three 18 months-old males only contained spermatogonia A and B. This was the initiation of spermatogenesis (Figure 8B). As the spermatogenesis continued, the gonads showed a gradual increase in the number of cysts containing cells at all the spermatogenetic stages.

Among 22 to 24 months-old animals, the presence of all germ cell types characterized an active spermatogenesis (Figure 8B) morphologically expressed by an increase of testes volume. One individual in which spermatocytes and more advanced cells were absent did not show any maturation sign.

During the spring of 2002, the four 26 months-old fish possessed spermatozoa into the lumen of lobules and in the strongly dilated deferent duct, so showing the characteristic of spermiation (Figure 8D). At this time, the cysts opened and released
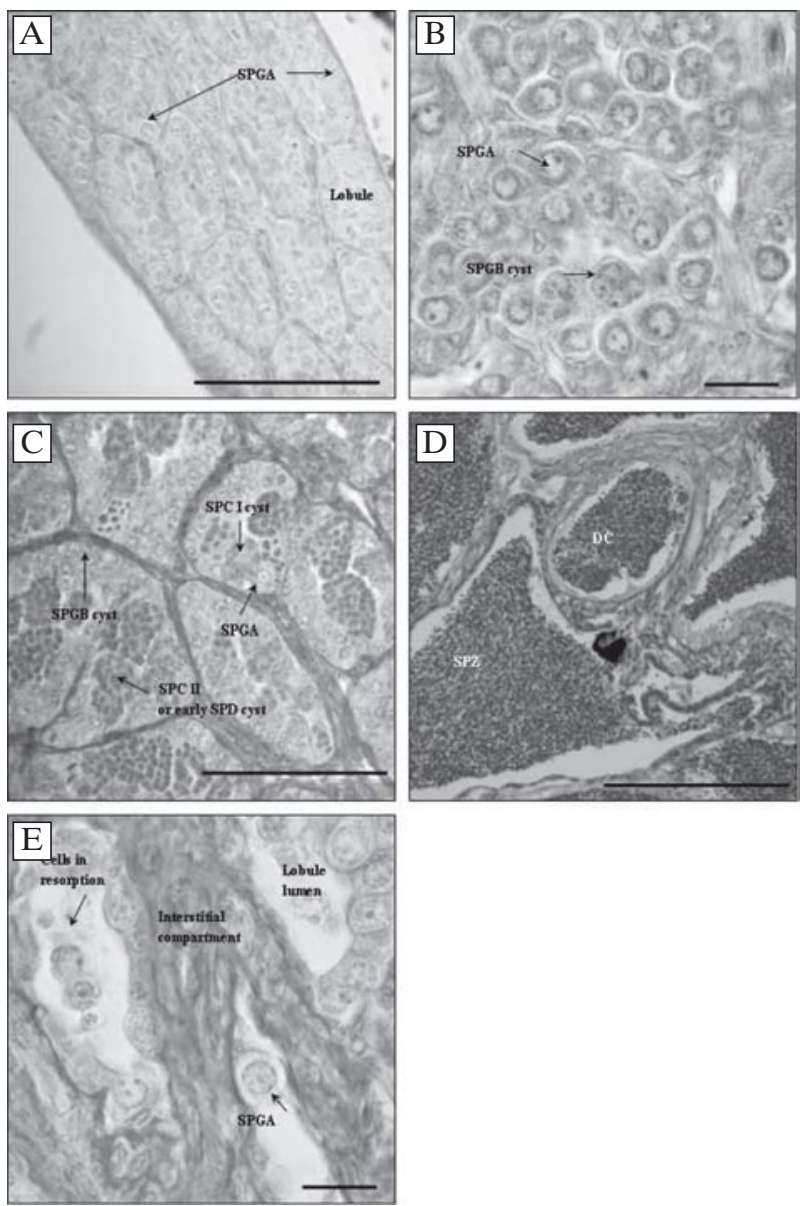

Figure 8. Histological sections of Zingel asper testis sampled between seven and 39 months old, showing sexual immaturity and the four stages of adult sexual development. Modified azan stained. A. Sexual immaturity.

B. Initial spermatogenesis. C. Active spermatogenesis. D. Spermiation. E. Post spawning. Scale bar $=100 \mu \mathrm{m}$. DC - deferent canal; SPGA - spermatogonia A; SPGB - spermatogonia B; SPC I — spermatocytes I; SPC II — spermatocytes II; SPD — spermatids;

SPZ - spermatozoa

spermatozoa into the lumen of lobules. The testes decreased in size.

During the summer of 2002, a single specimen presented post spawning testes. The gonads were again in the form of two thin ribbons. Lumen lobules were empty, or contained degenerated residual spermatozoa from the previous cycle. Spermatogenic cysts were lacking in the post spawning stage (Figure 8E); the wall of lobules was lined by Sertoli cells and few spermatogonia, and these were the only germ cells observed. Thus, the new generation of primary spermatogonia had already begun to develop when spermatozoa left testes. The connective tissue between the lobules was abundant.

The 2003 spring and summer samplings displayed an identical pattern to that of 2002. In March and 
April, the fishes were mature. All types of germs cells were present. Spermatozoa filled cysts, lobules lumens and deferent duct. In June, the $Z$. asper testes showed the characteristics of sexual rest.

\section{Discussion}

\section{Testis structure}

The structure of $Z$. asper testes are here described for the first time, using individuals aged between seven and 39 months.

In teleost fish, the fine morphology of the testis is variable, even within the same group [47]. In $Z$. asper, the testis is a paired elongated organ, located in the middle and anterior parts of the abdominal cavity, extending towards the tail, as in other teleost species $[4,48]$. The two testicular lobes can be completely fused $[49,50]$ or partially fused as in $Z$. asper and other percid species such as Perca fluviatilis [51] and Perca flavescens [52]. The Rhône streber testis is smooth, unlike some catfish which has fringed testis $[2,47,53]$. Furthermore, it does not possess any seminal vesicle as in other perciform species [54]. Each lobe has a deferens duct receiving SPZ. As in many teleost fish $[16,20,55]$, testicular ducts occupy almost the entire length of the testis and join at their caudal portion, forming the common spermatic duct, which extends to the urogenital papillae where semen is evacuated.

Seminiferous tubules of $Z$. asper have a blind end situated at the periphery of gonads, giving it a lobular structure [3, 17, 19, 47], as in most teleost fish [56, 57], and more particularly the perciform fish $[18,58,59]$.

The presence of type A spermatogonia all along the testicular lobules allows them to be characterized as unrestricted spermatogonial type [3, 4], as in other perciform species [22, 55, 59-61].

Grier $[17,62]$ defined the germinal epithelium as a tripartite structure including Sertoli cells, germinal cells and acellular basement membrane. It is commonly found in teleost fishes $[7,58,63]$ such as $Z$. asper.

Throughout the period of our study, the persistence of a permanent population of Sertoli cells, associated with germ cells, was observed. According to Billard [47] and Grier [17, 62], we may affirm it is a permanent germinal epithelium.

Mattei et al. [15] described two types of spermatogenesis: the cystic type, which is the more frequent $[1,5,57]$ and the semi-cystic type. In $Z$. asper the spermatogenesis was characteristic of the cystic type, because no germ cells, only SPZ, are released into the lumen of the seminiferous lobules.
The SPGA and SPGB observed are morphologically similar to teleost spermatogonia widely described in the literature by means of light microscopy [65-67] and electron microscopy $[22,53,68]$.

Many authors [7, 69] have characterized SPC I using the presence of an irregular condensed chromatin. The nucleoli have not always been distinguished [12, 65, 70]. In $Z$. asper, SPC I were marked by gradual condensation of chromatin and the nucleoli were rarely visible. SPC II had a very short life $[68,69]$; because of the speed of meiosis, they could not be clearly distinguished from the youngest SPD. During the development of young to mature SPD, the chromatin condensed and took a crescent shape into the nucleus. At the end of this stage, the nucleus was homogeneous and a flagellum developed at the posterior pole.

In the freshwater percids, such as the perch Perca fluviatilis [71] and the pike-perch Sander lucioperca [72], SPZ are monoflagellated. Our data shows that the spermatozoon of $Z$. asper has a single flagellum and a short middle piece not clearly differentiated from the head.

The diameters of the germ cells vary from one species to another, and sometimes within the same species [69]. Generally, as the result of successive divisions, cells have reduced in size [9], as observed in the Rhône streber. The diameters of the type A spermatogonia of $Z$. asper are among the highest reported for perciform fish, while SPGB, SPC I, SPC II and SPD diameters correspond to those generally reported for perciform fish [7, 70].

Teleost Sertoli cells form a network surrounding the developing germ cells $[3,73]$, as observed in sections of testes of $Z$. asper.

At the beginning of the sexual cycle of $Z$. asper, Sertoli cells were identifiable; they had a triangular or round nucleus as described by Andrade et al. [74].

After successive divisions, the cysts was considerably enlarged and the wall formed by the cytoplasm of Sertoli cells was stretched, either because of the cytoplasmic extension [75] or the multiplication of germ cells $[63,76]$. During spermiation, the cytoplasmic extensions of Sertoli cells became increasingly attenuated and appeared to break. After spermiation, the residual spermatozoa were reabsorbed by the Sertoli cells [25, 64, 77, 78].

Prisco et al. [79] hypothesized that some free and round-shaped Sertoli cells could continue their phagocytosis activity in the lumen of lobules, as has been noticed in the lumen lobules of $Z$. asper, during resorption of spermatozoa.

The cells close to blood vessels, sometimes in small groups, observed in $Z$. asper, are Leydig cells [57, 80]. 
Unlike other studies using light microscopy [7, 79], no evolution of these cells during $Z$. asper sexual cycle has been pointed out. Other cells, very elongated, along the basement membrane, are certainly identifiable as myoid cells $[21,80]$.

\section{Sexual maturity}

In teleosts, the age for sexual maturity is closely dependent on the species, the living conditions of the fish and their sex. Histological observations of the gonads of $Z$. asper aged between four and 36 months give an understanding of the age of sexual maturity. Generally $[34,81,82]$ and especially in percid species $[81,83]$, males tend to mature earlier than females. Our own observations showed that the puberty of males was initiated during the first year, and all males were mature by the third year. Most of the examined specimens achieved their first spermiation at the age of two years. They had reached their sexual maturity at the same age as the females [46]. By studying the growth curves of wild populations, Danancher [84] also assumed that the first maturation occurred approximately at two years.

However, individual variations exist, also reported by other authors [85]. The presence of ineffective spermatogenesis, characterized by a small amount of spermatozoa in lobular lumen and the absence of any other type of germ cells except spermatogonia, reveals a sexual precocity for some males $[10,86]$.

This precocious maturity can occur in fish bred in aquariums. Holland et al. [78, 86] noticed an accelerated maturity in certain breeding fish, which, unlike those living in the natural environment, are not subjected to the effects of environmental variations (photoperiod, temperature, food availability). In an aquarium, Dabrowski et al. [87] frequently observed Perca flavescens one year-old mature males, a phenomenon rarer in females.

In the Rhône streber living in the natural environment, Labonne [44] and Danancher [84] have reported a spawning period in March. According to our own observations, the final maturation of the sampling $Z$. asper however was observed later, in May, in conditions of captivity.

These results could be explained by the fact that the breeding tanks were supplied with water whose temperature varied only slightly during the year, and was just faintly warmer in spring.

\section{Dynamics of adult sexual cycle}

The annual sexual cycle of $\mathrm{Z}$. asper is a seasonal activity. It is divided into four stages, the initiation of spermatogenesis, active spermatogenesis, spermiation and resorption, as described in the literature [64]. The initiation of spermatogenesis, identified by the formation of spermatogonia B cysts, begins in September. The active spermatogenesis, when cysts of SPC I, SPC II, SPD and SPZ are present, is observed from January through March. The spermiation, with SPZ in the deferent canal, is first noticed in May. Among other percid freshwater fish (i.e. perch and pike-perch) spermiation takes place in spring, i.e early March to June, depending on the latitude [81, 83, 88-90]. The resorption, identified by some empty lobular lumens and SPZ in resorption, takes place in June and July.

The Rhône streber spermatogenesis is a continuous mechanism from September to May. According to Billard and Breton [32], this fish can be classified in group 2 of the reproductive cycle in which the gametogenesis begins in the fall, stops in winter and ends in spring. In captive conditions, blocking of sexual cycle during winter has not been observed in males as well as in females [46]. Thermal conditions may be involved here; the relatively mild winter temperatures of water do not delay the process of sexual development.

To confirm the sexual cycle type, this study should be repeated on wild fish. The sexual cycle and reproduction are essentially controlled by temperature and photoperiod variations, social factors and physical environment $[6,8,91]$. This seasonality is more pronounced in temperate zone species than in species that live in more stable habitats such as tropical or benthic environments [14].

The histological structures described in the different gonad stages in $Z$. asper closely corresponded to those of perciform fish. In $Z$. asper, individuals reach the adult stage at two years-old, and reproduction occurs in May in captive conditions. Our study has produced new information regarding reproductive physiology and so contributes to the conservation of $Z$. asper and the strategy to reintroduce it.

\section{Acknowledgements}

Thanks are due to Marie-Thérèse Laurent for her precious help with laboratory work.

\section{References}

1. Munoz M, Koya Y, Casadevall M. Histochemical analysis of sperm storage in Helicolenus dactylopterus dactylopterus (Teleostei, Scorpaenidae). J Exp Zool. 2002a;292:156-164.

2. Guimaraez-Cruz RJ, Dos Santos JE. Testicular structure of three species of neotropical freshwater pimelodids (Pisces, Pimelodidae). Rev Bras Zool. 2004;21:267-271.

3. Grier HJ, Linton JR, Leatheland JF, de Vlaming VL. Structural evidence of two testicular types in teleost fishes. Am J Anat. 1980;159:331-345. 
4. Grier HJ. Cellular organization of the testis and spermatogenesis in fishes. Am Zool. 1981;21:345-357.

5. Gusmao P, Foresti F, Quagio-Grassiotto I. Ultrastructure of spermiogenesis in Plagioscion squamosissimus (Teleostei, Perciforme, Sciaenidae). Tissue Cell. 1999;31:627-633.

6. Suwanjarat J, Amornsakun T, Thngboon L, Boonnyoung P. Seasonal changes of spermatogenesis in the male sand goby Oxyeleotris marmoratus Bleeker, 1852 (Teleostei, Gobiidae). Sonklanakarin J Sci Technol. 2005;27:425-436.

7. Fishelson L, Delarea Y, Gon O. Testis structure, spermatogenesis, spermatocytogenesis, and sperm structure in cardinal fish (Apogonidae, Perciforme). Anat Embryol. 2006;211: 31-46.

8. Billard R. La gamétogenèse, le cycle sexuel et le contrôle de la reproduction chez les poissons Téléostéens. B Fr Peche Piscic. 1979;273:117-136.=

9. Barnabe G. Reproduction chez les poissons. Bases biologiques et écologiques de l'aquaculture. Paris: Lavoisier; 1991.

10. Dziewulska K, Domagala J. Histology of salmonid testes during maturation. Reprod Biol. 2003;3:47-61.

11. Schulz RW, Miura T. Spermatogenesis and its endocrine regulation. Fish Physiol Biochem. 2002;26:43-56.

12. Lo Nostro FL, Grier H, Meijide FJ, Guerrerro GA. Ultrastructure of the testis in Synbranchus marmoratus (Teleostei, Synbranchidae), the germinal compartment. Tissue Cell. 2003;35:121-132.

13. Billard R, Jalabert B, Breton B. Les cellules de Sertoli des poissons téléostéens. I. Etude ultrastructurale. Ann Biol Anim Bioch. 1972;12:19-32.

14. Pudney J. Spermatogenesis in nonmammalian vertebrates. Microsc Res Tech. 1995;32:459-497.

15. Mattei X, SIiau Y, Thiaw OT, Thiam D. Peculiarities in the organization of testis of Ophidion sp. (Pisces, Teleostei). Evidence of two types of spermatogenesis in teleost fish. $J$ Fish Biol. 1993;43:931-937.

16. Legendre M, Jalabert B. Physiologie de la reproduction. In: Biologie et écologie des poissons d'eau douce africains (Lévèque C., Bruton M.N. \& Ssentongo G.W. eds) pp. 153 187. 1988. Paris: Orstom.

17. Grier HJ. Comparative organization of Sertoli cells including the Sertoli cell barrier. In: Russell LD, Griswold MD, eds. The Sertoli cell. Clearwater, Flo: Cache River Press; 1993:704-736.

18. Grier HJ, Taylor RG. Testicular maturation and regression in the common snook. J Fish Biol. 1998;53:21-542.

19. Mellinger J. Sexualité et reproduction chez les poissons. Paris: CNRS editions; 2002

20. Selman K, Wallace RA. Gametogenesis in Fundulus heteroclitus. Am Zool. 1986;26:173-192.

21. Cauty C, Loir M. The interstitial cells of the trout testis (Oncorhynchus mykiss), ultrastructural characterization and changes throughout the reproductive cycle. Tissue Cell. 1995;27:383-395.

22. Fishelson L. Comparison of testes structure, spermatogenesis, and spermatocytogenesis in young, aging, and hybrid cichlid fish (Cichlidae, teleostei). J Morph. 2003;256:285-300.

23. Rutaisire J, Muwazi RT, Booth J. Ultrastructure description of spermiogenesis and spermatozoa in Labeo victorianus Boulenger, 1901 (Pisces, Cyprinidae). Afr J Ecol. 2006;44: 102-105.

24. Thomé RG, Bazzoli N, Rizzo E, Santos GB, Ratton FR. Reproductive biology of Leporinus taeniatus Lütken (Pisces, Anostomidae) in Juramento Reservoir, Săo Francisco River basin, Minas Gerais, Brazil. Rev Bras Zool. 2005;22:565-570.
25. Billard R, Escaffre AM. Identification des stades de la spermatogenèse de la truite fario d'après la morphologie des gonades et la spermiation. B Fr Peche Piscic. 1975;256: 111-118.

26. Sokolowska E, Kulczykowska E. Annual reproductive cycle in two free living populations of three-spined stickleback (Gasterosteus aculeatus L.), patterns of ovarian and testicular development. Oceanologia. 2006;48:103-124.

27. Koya Y, Soyano K, Yamamoto K, Obana H, Matsubara T. Testicular development and serum profiles of steroid hormone levels in captive male pacific herring Clupea pallasii during their first maturation cycle. Fish Sci. 2002;68:1099-1105.

28. Billard R, Weil C, Bieniarz K et al. Testicular and some hormonal changes during the first four years of life in the mirror carp, Cyprinus carpio L. J Fish Biol 1992;41:473-487.

29. Modesto T, Canario AVM. Morphometric changes and sex steroid levels during the annual reproductive cycle of the lusitanian toadfish, Halobatrachus didactylus. Gen Comp Endocrinol. 2003;131:220-231.

30. Hojo RES, Santos GB, Bazzoli N. Reproductive biology of Moenkhausia intermedia (Eigenmann) (Lütken) (Pisces, Characiforme) In Itumbiara reservoir Goiás, Brazil. Rev Bras Zool. 2004;21:519-524.

31. Weltzein FA, Taranger GL, Karlsen O, Norberg GB. Spermatogenesis and related plasma androgen levels in Atlantic halibut (Hippoglossus Hippoglossus L.). Comp Biochem Physiol Part A. 2002;132:567-575.

32. Billard R, Breton B. Le cycle reproducteur chez les poissons téléostéens. Cah Lab Montereau. 1981;12:43-56.

33. Lalancette LM. The seasonal cycle in the germinal cells (testes and ovaries) of the white sucker, Catostomus commersoni, of Gamelin lake, Québec. Nat Can. 1975;102:721-736.

34. Yoneda M, Tokimura M, Fujita $\mathrm{H}$ et al. Reproductive cycle, fecundity, and seasonal distribution of the angler fish Lophius litulon in the East China and Yellow Seas. Fish Bull. 2001;99:356-370.

35. Perrin JF. Maintien en aquarium de l'apron du Rhône, Zingel asper (L.), espèce menacée d'extinction. Rev Fr Aquariol. $1988 ; 15: 17-20$

36. Changeux T, Pont D. Current status of the riverine fishes of the French Mediterranean basin. Biol Conserv. 1995;72:137-158.

37. Boutitie F. L'apron, poisson rare menacé de disparition (Biologie, Répartition, Habitat). DEA, 1984. Univ. Lyon1, Villeurbanne, France.

38. Cavalli L, Pech N, Chappaz R. Diet and growth of the endangered Zingel asper in the Durance River. J Fish Biol. 2003;63:460-471.

39. Labonne J, Gaudin P. Exploring population dynamics patterns in a rare fish, Zingel asper, through capture-mark-recapture methods. Conserv Bio. 2005;19:463-472.

40. Labonne J, Gaudin P. Modelling population viability in fragmented environments, contribution to the conservation of an endangered percid (Zingel asper). Can J Fish Aquat Sci. 2006;63:650-659.

41. Danancher D, Labonne J, Pradel R, Gaudin NP. Capture Recapture Estimates of Space Used in Streams (CRESUS) at the population scale, case study on Zingel asper (percid), a threatened species of the Rhone catchment. Can J Fish Aquat Sci. 2004;61:476-486.

42. Danancher D, Izquierdo JI, Garcia-Vazquez E. Microsatellite analysis of relatedness structure in young of the year of the endangered Zingel asper (Percidae) and implications for conservation. Freshwater Biol. 2008;53: 546-557. 
43. Laroche J, Durand JD. Genetic structure of fragmented populations of a threatened endemic percid of the Rhône river, Zingel asper. Heredity. 2004;92:329-334.

44. Labonne J. Contribution à la conservation de l'apron du Rhône (Zingel asper): Dynamique des populations, sélection de l'habitat, et modélisation. Ph.D. Thesis. 146 p. 2002.Univ. Lyon 1, Villeurbanne, France.

45. Mari S. Guide de gestion pour la conservation de l'apron du Rhône, Réserves Naturelles de France. 2001. Available at: http://www.apron.reserves-naturelles.org.

46. Chevalier C, De Conto C, Goubier V, Hardy I, Exbrayat JM. Etude du développement folliculaire ovarien chez Zingel asper (Percidae). Cybium. 2005;29:327-338.

47. Billard R. Discussion de quelques données sur la spermatogenèse des poissons et sur l'adaptation des spermatozoïdes aux conditions de fécondation dans divers milieux. La Piscic fr. 1990;101:24-40.

48. Nagahama Y. Testis. In: Pang PKT, Schreibman MP, Gorbman A, eds. Vertebrate endocrinology, fundamentals and biomedical implications. New York: Academic Press; 1986:399-437

49. Billard R. La spermatogenèse de Poecilia reticulata. I) Estimation du nombre de générations goniales et rendement de la spermatogenèse. Ann Biol Anim Bioch. 1969;9:251-271.

50. Billard R. Spermatogenesis and spermatology of some teleost fish species. Reprod Nutr Dev. 1986;26:877-920.

51. Treasurer JW, Holliday GT. Some aspects of the reproductive biology of perch Perca fluviatilis L. A histological description of the reproductive cycle. J Fish Biol. 1981;18:359-376.

52. Turner CL. The seasonal cycle in the spermary of the perch. J Morph. 1919;32:681-711.

53. Santos JE, Bazzoli N, Rizzo E, Santos GB. Morphological organisation of the male reproductive system of the catfish Iheringichtys labrosus (Lütken, 1874) (Siluriforme, Pimelodidae). Tissue Cell. 2001;33:533-540.

54. Cinquetti R. Histochemical, enzyme histochemical and ultrastructural investigation on the sperm-duct glands of Padogobius martensi (Pisces, Gobiidae). J Fish Biol. 1997;50: 978-991.

55. Manni L, Rasotto MB. Ultrastructure and histochemistry of the testicular efferent duct system and spermiogenesis in Opistognathus whitehurstii (Teleostei, Trachinoidei). Zoomorphol. 1997;177:93-102.

56. Billard R, A quantitative analysis of spermatogenesis in the trout, Salmo trutta fario. Cell Tissue Res. 1983;230:495-502.

57. Rutaisire J, Muwazi RT, Booth J. Structure and cytology of the testes of Labeo victorianus (Pisces, Cyprinidae). Afr Zool. 2003;38:119-126.

58. Lee TH, Chiang TH, Huang BM, Wang TC, Yang HY. Ultrastructure of spermatogenesis of the paradise fish, Macropodus opercularis. Taiwania. 2006;51:170-180.

59. Huang JD, Lee MF, Chang CF. The morphology of gonadal tissue and male germ cells in the protandrous black porgy, Acanthopagrus schlegeli. Zool Stud. 2002;41:216-227.

60. Hardy I, Martin M, Exbrayat JM, Goubier V. Application des microscopies photonique et électronique à balayage à la mise en évidence du cycle sexuel mâle du black-bass (Micropterus Salmod'des L.) au cours d'un cycle. Rev Fr Histotechnol. 2002;15:73-80.

61. Parenti LR, Grier HJ. Evolution and phylogeny of gonad morphology in bony fishes. Integr Comp Biol. 2004;44:333-348.

62. Grier HJ. Chordate testis, the extracellular matrix hypothesis. J Exp Zool. 1992;261:151-160.

63. Koulish S, Kramer CR, Grier HJ. Organization of the male gonad in a protogynous fish, Thalassoma bifasciatum (Teleostei, Labridae). J Morph. 2002;254:292-311.
64. Da Cruz-Landim C, Abdalla FC, Cruz-Höfling MA. Morphological changes of Sertoli cells during the male reproductive cycle of the teleost Piaractus mesopotamicus (Holmberg, 1887). Braz J Biol. 2005;65:241-249.

65. Munoz M, Sabat M, Mallol S, Casadewall M. Gonadal structure and gametogenesis of Triga lyra (Pisces, Triglidae). Zool Stud. 2002b;41:412-420.

66. Guimaraes-Cruz RJ, Santos JE, Santos GB. Gonadal structure and gametogenesis of Loricaria lentiginosa Isbrücker (Pisces, Teleostei, Siluriforme). Rev Bras Zool. 2005;22: 556-564.

67. Santos RN, Andrade CC, Santos LN, Santos AFGN, Araujo FG. Testicular maturation of Oligosarcus hepsetus (Cuvier) (Actinopterygii, Characidae) in a Brazilian reservoir. Braz J Biol. 2006;66:143-150.

68. Miura T. Spermatogenetic cycle in fish. In: Knobil E, Neill JD eds. Encyclopedia of reproduction. New York: Academic Press; 1999:571-578.

69. Nagahama Y. The functional morphology of teleosts gonads. In: Hoar WS, Randall DJ, Donalson EM eds. Fish physiology. New York: Academic Press;1983:223-275.

70. Raizada AK. The testicular cycle of a Percoid teleost. Gegenbaurs morphol Jahrb. 1975;121:77-87.

71. Lahnsteiner F, Berger B, Weismann I, Patzner RA. Fine structure and mobility of spermatozoa and composition of the seminal plasma in the perch. $J$ Fish Biol. 1995;47:492-508.

72. Lahnsteiner F, Mansour N. Sperm fine structure of the pikeperch, Sander lucioperca (Percidae, Teleostei). J Sub Cytol Path. 2004;36:309-312.

73. Groman DB. Histology of the striped bass. Am Fish Soc. Monogr. 3 Bethesda, Maryland; 1982.

74. Andrade RF, Bazzoli N, Rizzo E, Sato Y. Continuous gametogenesis in the Neotropical freshwater teleost, Bryconops affinis (Pisces, Characidae). Tissue Cell. 2001;33: 524-532.

75. Pudney J. Comparative cytology of the nonmammalian vertebrates Sertoli cell. In: Russell LD, Griswold MD, eds. The Sertoli cell. Clearwater, Flo: Cache River Press; 1993:611-657.

76. Schulz RW, Menting S, Bogerd J, França LR, Vilelad DAR, Godinho HP. Sertoli cell proliferation in adult testis - evidence from two fish species belonging to different orders. Biol Reprod. 2005;73:891-898.

77. Billard R. La production spermatogénétique chez la truite. Ann Biol Anim Bioch. 1971;11:190-212.

78. Holland MC, Hassins S, Zohat Y. Gonadal development and plasma steroid levels during pubertal development in captive-reared striped bass, Morone saxatilis. J Exp Zool. 2000; 286:49-63.

79. Prisco M, Liguoro A, D'onghia B, Ricchiari L, Andreauccetti P, Angelini F. Fine structure of Leydig and Sertoli cells in the testis of immature and mature spotted ray Torpedo marmorata. Mol Reprod Dev. 2002;63:192-201.

80. Grier HJ, Van den Hurk R, Billard R. Cytological identification of cell types in the testes of Esox lucius and E. niger. Cell Tissue Res. 1989;257:491-496

81. Papageorgiou NK. Fecundity and reproduction of perch (Perca fluviatilis L.) in Lake Agios Vasilios, Greece. Freshwater Biol. 1977;7:559-565.

82. Jalabert B. Particularities of reproduction and oogenesis in teleost fish compared to mammals. Reprod Nutr Dev. 2005;45:261-279.

83. Jamet JL, Desmolles F. Growth, reproduction and condition of roach (Rutilus rutilus (L.)), perch (Perca fluviatilis, L.) and ruffe (Gymnocephalus cernuus (L.)) in eutrophic lake Aydat (France). Int Rev Ges Hydrobiol. 1994;79:305-322. 
84. Danancher D. Apport de l'écologie comportementale à la conservation d'un poisson en voie de disparition, l'apron du Rhône (Zingel asper). Ph.D. Thesis. 2005, 167 p. Univ. Lyon 1, Villeurbanne, France.

85. Iliadou K, Fishelson L. Histology and cytology of testes of the catfish Parsilurus aristotelis (Siluridae, Teleostei) from Greece. Jpn J Ichthyol. 1995;41:447-454.

86. Holland MC, Mylonas CC, Zohar Y. Sperm characteristics of precocious 1-year-old male striped bass Morone saxatilis. J World Aquac Soc. 1996;27:208-212.

87. Dabrowski K, Cieresko RE, Cieresko A et al. Reproductive physiology of yellow perch (Perca flavescens), environmental and endocrinological cues. J Appl Ichthyol. 1996;12:139-148.
88. Malison JA, Held JA. Reproduction and spawning in walleye (Stizostedion vitreum). J Appl Ichthyol. 1996;12: 153-156.

89. Schlumberger O, Proteau JP. Reproduction of pike-perch (Stizostedion lucioperca) in captivity. J Appl Ichthyol. 1996; 12:149-152.

90. Sulistyo I, Fontaine P, Rinchard J et al. Reproductive cycle $\&$ plasma levels of steroids in male Eurasian perch Perca fluviatilis. Aquat Living res. 2000;13:99-106.

91. Borg B. Seasonal effects of photoperiod and temperature on spermatogenesis and male secondary sexual characters in the three-spined stickleback, Gasterosteus aculeatus L. Can J Zool. 1982;60:3377-3386.

Submitted: 18 November, 2010 Accepted after reviews: 1 March, 2011 